\title{
AHP-Consensus Judgement on Transitional Decision-Making: With a Discussion on the Relation towards Open Innovation
}

\author{
Mohd Fakhrur Razi Misran ${ }^{1, *(\mathbb{D})}$, Eida Nadirah Roslin ${ }^{2, *}$ and Nurhayati Mohd Nur ${ }^{3}$ \\ 1 Department of Mechanical (Automotive), Politeknik Kuching Sarawak, Kuching 93050, Sarawak, Malaysia \\ 2 Automotive Engineering Section, University Kuala Lumpur Malaysia France Institute (UniKL-MFI), \\ Bandar Baru Bangi 43650, Selangor, Malaysia \\ 3 Department of Aerospace, Universiti Kuala Lumpur Malaysian of Aviation Technology (UniKL-MIAT), \\ Dengkil 43800, Selangor, Malaysia; nurhayatimn@unikl.edu.my \\ * Correspondence: mfakhrurrazimisran@gmail.com (M.F.R.M.); eidanadirah@unikl.edu.my (E.N.R.)
}

Received: 29 June 2020; Accepted: 10 August 2020; Published: 12 August 2020

\begin{abstract}
Green and sustainable engineering business models have become a major topic across industries due to concerns regarding environmental issues and the decline of natural resources. Remanufacturing is showing promise as a preferable solution in terms of environmental, societal, and economic factors compared to alternatives such as repairing, reconditioning, and recycling. By considering the nature of the closed cycle loop system, this paper proposes the idea of a transitional agenda into remanufacturing. However, different countries should employ different approaches to such a transition in order to appropriately account for and integrate diverse stakeholders, perspectives, and preferences. Therefore, the main objective of this study is to evaluate prioritized elements and sub-elements in the development of a transitional decision-making framework (TDMF) in the Malaysian automotive industry by applying the analytical hierarchy process (AHP). Aggregation of individual and group judgement is done for prioritised elements and their sub-elements, which are then ranked accordingly using element weights based on the acceptance of individual and group consistency index values.
\end{abstract}

Keywords: remanufacturing; transitional; analytic hierarchy process; group decision making; consistency

\section{Introduction}

Green and sustainable engineering practices have represented a substantial paradigm shift among both researchers and industries. The $4 \mathrm{R}$ concept has been introduced which consists of repairing, reconditioning, remanufacturing, and recycling. Among these approaches, remanufacturing has become a favoured approach for maintaining comprehensive competitive advantages in terms of economic [1], environmental [2,3], and societal [4] aspects, while increasing profitability. Economically, remanufacturing promises a strategic advantage to companies compared to brand new manufacturing. The core is acquired from end-of-life (EOL) parts as a primary resource, thus allowing the company to benefit from a $50 \%$ cost reduction, a $40 \%$ saving on energy consumption, and a 30\% saving on materials [5,6] compared to an organisation manufacturing brand new products, which consume $100 \%$ of the cost of materials and energy during their production [1]. Due to its connection to sustainable manufacturing, remanufacturing has received significant attention in recent years from both developing and developed countries such as the United States (USA), China [7,8], Japan [9], Brazil [10], India [11], and Thailand [12] with multiple progressive strategic plans and employment of different methods and approaches, depending on demographic issues, political support, financial strength, and technological capabilities.

With acknowledgement of the capability of remanufacturing, Malaysia has highlighted the importance of adaption and implementation of the remanufacturing concept in the automobile industry. In Malaysia 
alone, as reported by the Malaysia Automotive Association (MAA), more than half a million new vehicles have been registered since 2010, with Proton and Perodua as a vehicle manufacturer company accounting for approximately $60 \%$ of the total industry volume (TIV) [13]. Remanufacturing is suggested as an effective means of end-of-life (EOL) vehicle management. It has been forecast to potentially reach RM 670 million with further projected increment by 2020 [14] from the current RM207-345 million, which would contribute greatly to the Malaysian economy while reducing emissions and energy waste.

The initiatives are focused on promoting environmental awareness as well as the implementation of remanufacturing from the other green practices of companies, such as repair, recondition, and recycle, due to the nature of the closed-loop cycle [15] of the green practices system. The only issue is whether Malaysian enterprises are ready and willing to adopt remanufacturing practices and transform into remanufacturers. Environmental protection and the sustainability agenda demand that decisive steps are taken, including on-going initiatives and cooperation between the government and various other stakeholders [16]. In other words, it is a business transition related with multi-actor or societal-system changes towards sustainability.

The agenda of business transition entails a strategic transition management procedure. The two approaches comprehensively applied in the transition process are adaptive management and transition management $[17,18]$. Adaptive management approach is a significant method in dealing with sustainability of social-ecological system changes by learning the process from extended experimental investigation $[19,20]$. Meanwhile, transition management is related to sustainability development based on social-technical system changes [21]. It involves years of exploration for transformation agenda from diverse professionalisms and perspectives which are essential for providing a long-term target, and continuous experimental experience in structures and actors [22,23] for determining a functioning system as well as business innovation sustainability [24]. Loorbach et al. [25] further emphasised that activities involving societal change should be observed and differentiate by proposing four major elements namely strategic, tactical, operational, and reflexive.

With comparison of these two transition management approaches, this study is interested in adapting the transition management framework as employed by Loorbach et al. [25] in the transition to remanufacturing in Malaysia. The main reason is the transition from other green strategies to remanufacturing has posed a significant challenge that entails addressing the priorities and requirements from a diverse range of perspectives, particularly the viewpoints of the government and numerous industry stakeholders. Therefore, businesses currently implementing repair and rebuild practices require knowledge guidance to reach a consensus judgment amongst their decision makers to successfully transition to remanufacturing. A better mutual understanding of transition plans and strategies will be an advantage in adapting the transformation of an organization into a successful remanufacturer. Thus, this study focuses on evaluating the prioritized elements and sub-elements in the development of a transitional decision-making framework (TDMF) which drawn from multi-perspective and professionalism background by using an analytical hierarchy process (AHP).

\section{Methods}

\subsection{Elements and Sub-Elements Selection}

As explained in Section 1, this study is interested in adapting the transition management framework as proposed by Loorbach et al. [25] and the four elements in transitional business strategies which are strategic, tactical, operational, and reflexive. The strategic element is a process of developing mutual understanding by determining alternatives and problem structuring while envisioning the establishment of the transition arena for a long-term objective through individual opinion and politics. Then, to implement the tactical element, companies need to identify potential partners who will support the transformation process and help attain sustainable objectives. The operational element is the continual improvement and development of various aspects such as technology, practices, and product. The daily working procedure may require a change in normal practices and restructuring to increase the effectiveness of sustainable 
systems. The reflexive element is a process of examining each activity of current practices so that any misleading information can be identified in relation to organisation, product, process, or environment. Each of these elements expresses a different analysis purpose as supported by [26].

Two steps were taken: (1) from literature review, and (2) conducting case study. The sub-elements for transition process into remanufacturing are identified from the first step. A total of 14 sub-elements were identified from the review process. Then, the study proceeds with the case study. The main purpose of this step is to understand the real-life practice within these business activities, and it contributes to categorizing the sub-element into four major elements as shown in Table 1. Site exploratory case studies were conducted at only two companies as recommended by Malaysia Automotive, Robotic \& IoT Institute (MARii) due to confidentiality issues, time constraints, and their willingness to participate. The only selection criteria for the case studies were that they implement alternative green practices such as rebuilding and restoration vehicle parts. Data was collected through interview sessions with key operational personnel such as the general manager or senior production engineer. For matter confidentiality, each company is simply referred to as Company A and Company B. The interview sessions were conducted simultaneously with site observations as well as an adapted open-ended questionnaire [10] to allow flexibility in understanding the questions and in providing answers [27]. Apart from that, company reports and other information were gathered to reaffirm the results. For further details on findings about the case studies, please refer to our prior previous study conducted by Misran et al. [28].

Table 1. Classification of transitional decision-making framework (TDMF) sub-elements.

\begin{tabular}{ccc}
\hline Elements & Sub-Elements & References \\
\hline \multirow{3}{*}{ Strategic Element (SE) } & Formulate Vision and Goal (FVSG) & {$[29,30]$} \\
& Develop Supply Chain System (DSCS) & {$[30-32]$} \\
& Develop Financial Strategies (DFS) & {$[33,34]$} \\
& Formulate Marketing Strategies (FMS) & {$[26,35]$} \\
\hline \multirow{2}{*}{ Tactical Elements (TE) } & Develop Organization Support (DOS) & {$[36-38]$} \\
& Collaborate with OEM (COEM) & {$[9,39-41]$} \\
& Collaborate with Government (CG) & {$[9,42]$} \\
Operational Element (OE) & Collaborate with Research Institution (CRI) & {$[43,44]$} \\
& Process Chain/Core Management Process (DPC) & {$[48,49]$} \\
& Formulate Data/Documents Management (FDDM) & {$[50,51]$} \\
\hline \multirow{3}{*}{ Reflexive Element (RE) } & Human Resources Development (HRD) & {$[52,53]$} \\
& Organization Evaluation (OV) & {$[54-56]$} \\
& Society Engagement (SOE) & {$[57,58]$} \\
\hline
\end{tabular}

\subsection{Application of AHP in Development of Transitional Decision-Making Framework (TDMF)}

AHP is one of the multi-criteria decisions making (MCDM) methods. Several MCDM tools are applied depending on the problem cases, such as elimination and choice translating reality (ELECTRE), preference ranking organisation method for enrichment evaluation (PROMETHEE), SMART and TOPSIS. However, among the MCDM methods, AHP is widely used in decision-making approaches in several fields such as public-cooperation problem types, strategic policies, and management planning $[59,60]$. AHP is a theory and involves mathematical process of measurements based on an expert's judgement on pairwise comparison with a scale provided. The scale represents dominant attributes better compared to the other options. AHP is a reliable decision-making tool because it deals with the prioritised elements and sub-elements. Five phases of AHP application are used in the study, which are illustrated in Figure 1. 


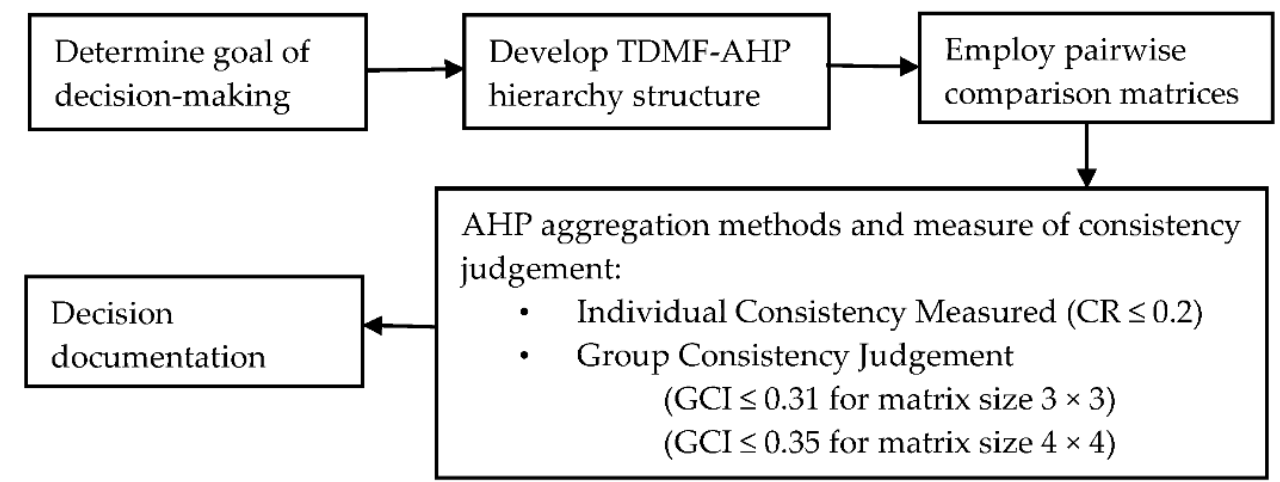

Figure 1. Methodology of the analytical hierarchy process (AHP) group decision-making process.

\subsubsection{Define the Goal}

In decision making, the ability to define the issue, problem, or goal is required to enable the decision makers to identify related elements and sub-elements relevant to the discussed issue, which affect particular groups and stakeholders [61]. In the case of this research, the goal is to evaluate the prioritised element and sub-element for transition process in remanufacturing business operation. No sub-goals are required in this research.

\subsubsection{TDMF-AHP Hierarchy Structure}

Driven factors and prioritised elements are different in the transition agenda, which creates a challenge. Organisation should identify prioritised elements to formulate strategic planning process so that it can remain conscious of the possible impact of its decision [62]. Thus, the desired requirements could be obtained by evaluating and ranking accordingly [63] using the AHP method. The identified elements and sub-elements as discussed in Section 2.1 are arranged accordingly in a hierarchy structure from top to bottom (from goal to design alternative), as shown in Figure 2. The hierarchy consists of three layers, and in some cases, it could be reduced to a two-layer decision tree, depending on the research issues.

\subsubsection{Pairwise Comparison Matrix}

All elements and sub-elements as presented in the form of hierarchal structure, which will be evaluated by applying pairwise comparison matrix. It can be done by distributing designed questionnaires to selected respondents, experts, or decision makers. For a given element, a decision maker makes a judgement on weighting the element and sub-elements with the scale ranging from one to nine, as shown in Table 2; these rankings are presented in a matrix form. The size of the matrix $(n \times m)$ depends on the number of elements:

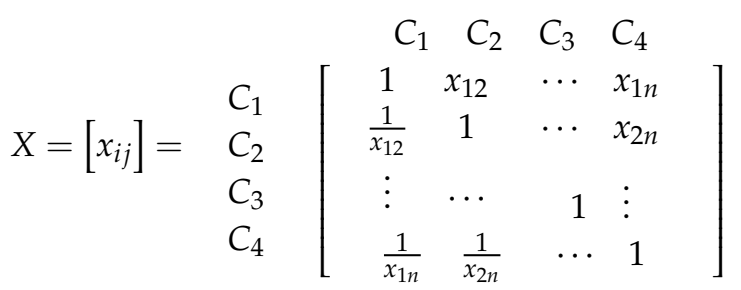

Equation (1) demonstrates matrix $X$, which represents $X=\left[x_{i j}\right]$ and the comparison element value is $\left[x_{i j}\right]=\frac{1}{x_{j i}}$ for $i \neq j$ where $i$ is the n-column of the matrix and $j$ is the m-row of the matrix. Meanwhile, the judgement values by the expert are demonstrated by the element $x_{i j}$. The diagonal numbers are equal to 1 since feature $\left[x_{i j}\right]=1$. In addition, the elements $C_{1}, C_{2}, \ldots C_{n}$ are designated for the element. 


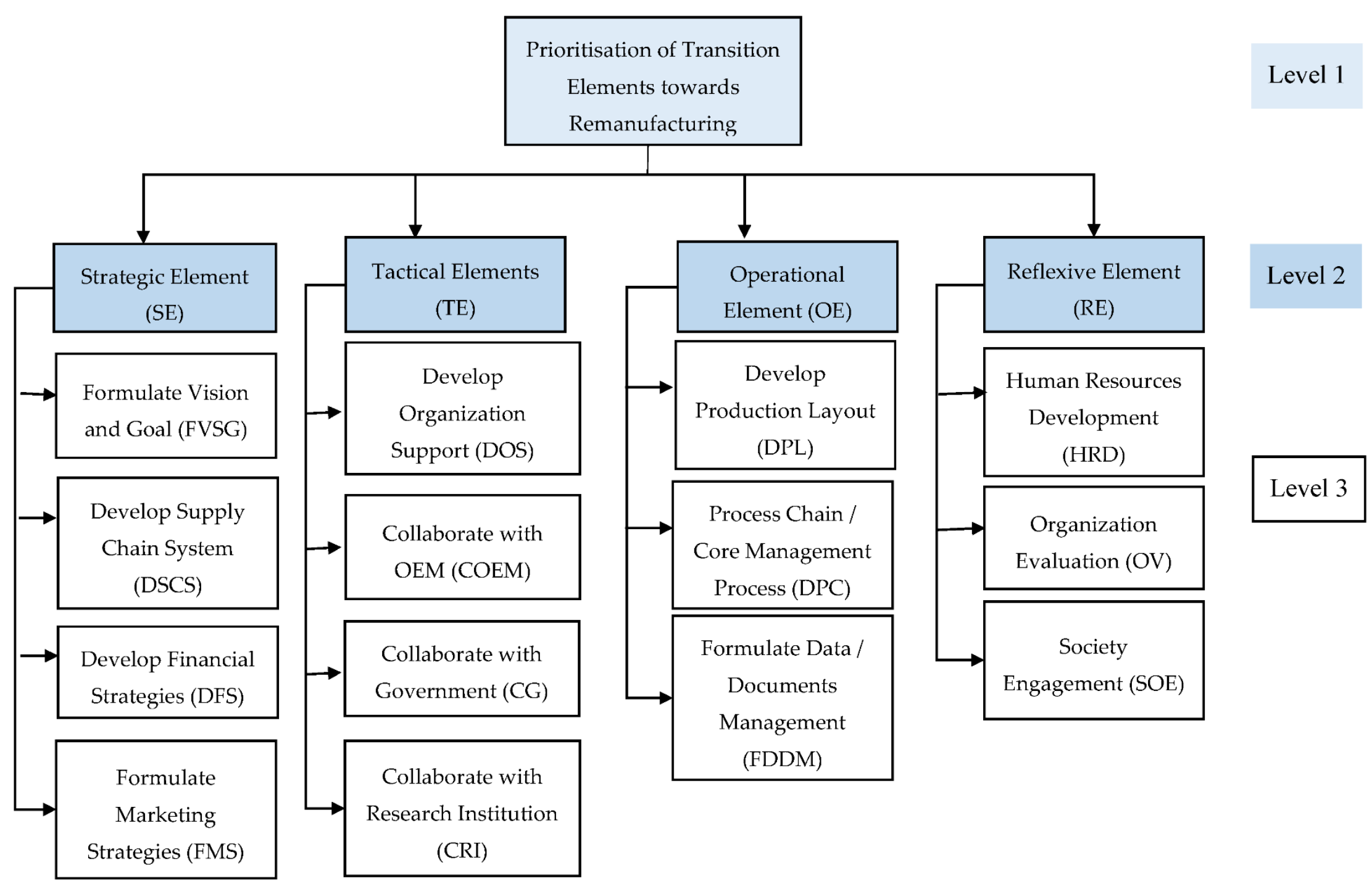

Figure 2. Hierarchal structure of transitional elements. 
Table 2. Importance scale of pairwise comparison process [64].

\begin{tabular}{|c|c|c|}
\hline Importance Scale & Definition & Explanation \\
\hline 1 & Equally important & $\begin{array}{l}\text { Two activities contribute equally to } \\
\text { the objective }\end{array}$ \\
\hline 3 & Moderately important & $\begin{array}{l}\text { Experience and judgement slightly favour } \\
\text { one activity over another }\end{array}$ \\
\hline 5 & Strongly important & $\begin{array}{l}\text { Experience and judgement strongly } \\
\text { favour one activity over another. }\end{array}$ \\
\hline 7 & Very strong or demonstrates importance & $\begin{array}{l}\text { An activity is favoured very strongly over } \\
\text { another. Its dominance demonstrated } \\
\text { in practice. }\end{array}$ \\
\hline 9 & Extremely important & $\begin{array}{c}\text { The evidence favouring one activity over } \\
\text { another is of the highest possible order } \\
\text { of affirmation. }\end{array}$ \\
\hline $2,4,6,8$ & $\begin{array}{l}\text { Intermediate values between the two } \\
\text { adjacent judgments }\end{array}$ & When compromise is needed. \\
\hline $\begin{array}{l}\text { Reciprocals of } \\
\text { above }\end{array}$ & $\begin{array}{c}\text { If activity } i \text { has one of the above non-zero } \\
\text { numbers assigned to it when compared } \\
\text { with activity } j \text {, then } j \text { has the reciprocal } \\
\text { value when compared with } i \text {. }\end{array}$ & A reasonable assumption. \\
\hline
\end{tabular}

\subsection{Respondent Classification and Survey Distribution}

For obtaining confidence in pairwise comparison judgement, the selection of respondent depends on the scope and aim of the study. The number of participating experts varies from three to 25 [65-69]. Five experts with thorough experience were involved in this study. The experts were drawn from government establishment, industries, and academia. One expert representing the authorities' enforcement body has an experience of 10 years in Road Transport Department of Malaysia. The department is actively involved in evaluating and auditing the automotive business activities in Malaysia, such as repairing, reconditioning, and remanufacturing of vehicle components. Two experts are in managerial level and engineer levels from industries and have experience in their professional fields for more than seven years. One of the industrial experts owns two registered companies in repairing and recondition vehicle body as well as logistic and transportation and is well-experienced in automotive business management. Another expert from industries is a senior engineer at one of the original equipment manufacturer (OEM) company, which deals with manufacturing and design development of vehicle components. All the experts from industries also have decision-making experiences with regards to their professions. The remaining two experts involved in this study are from academics. They are experienced in research and article publication related to operations management, environmental technological innovation, and automotive industries and engineering. Both academia experts have been working in their current roles for more than seven years. In fact, one of the academia experts had worked in the industry for almost 13 years before joining the academic world. The experts' details are summarised in Table 3.

Table 3. Respondents classification.

\begin{tabular}{ccc}
\hline Major & Organisation & Professional Experience \\
\cline { 1 - 2 } Expert 1 & Government Authority Enforcement Body & \multirow{2}{*}{ More than 10 years } \\
\cline { 1 - 2 } Expert 2 & Private Company (Managerial level) & \\
\cline { 1 - 2 } Expert 3 & OEM Company (Senior engineer) & \\
\cline { 1 - 2 } Expert 4 & University Researcher & More than 7 years \\
\cline { 1 - 2 } Expert 5 & & \\
\hline
\end{tabular}


After identifying the experts, survey forms were distributed to each of them through multiple communication mediums such as email, personal interview and telephone, considering the time constraint and cost-effectiveness in data collection process. The survey form consists of three major steps. In Step (1), elements and sub-elements for the transition into remanufacturing were described to ensure that the respondents understand the definition for each elements and sub-elements. In Step (2), the respondents were once again guided on answering the pairwise comparison survey (refer to Appendix A Table A1) before taking the real question. Step (3) dealt with demographic information of respondents.

\subsection{AHP Aggregation Methods and Consistency Judgement Measurement}

Applying individual judgment to a consensus decision is questionable if inconsistency features from the beginning. The vital point on this issue is how the individual judgements can be accepted and considered to be consistent in making a judgment. Therefore, the individual prioritised vector (eigenvalue method), consistency index (CI), and consistency ratio (CR) are used as shown in the following equations:

$$
\begin{gathered}
X w=\Lambda w ; e^{T} w=1 \\
C I=\frac{\Lambda_{\max }-n}{n} \\
C R=\frac{C I}{R I}
\end{gathered}
$$

where $K_{\text {max }}$ is the maximum eigenvalue of $X, n$ is the matrix size, and RI is a random index. Table 4 shows the accepted RI value based on the matrix size. As a rule of thumb, a CR value of less than 0.1 or $10 \%$ is considered sensible. If the CR value is between $10 \%$ and $20 \%$, it is considered reasonable [70-72]. However, any $\mathrm{CR}$ value more than $20 \%$ should not be accepted and requires re-evaluation.

Table 4. Random index (RI) references [64].

\begin{tabular}{cccccccccc}
\hline $\mathbf{n}$ & $\mathbf{1}$ & $\mathbf{2}$ & $\mathbf{3}$ & $\mathbf{4}$ & $\mathbf{5}$ & $\mathbf{6}$ & $\mathbf{7}$ & $\mathbf{8}$ & $\mathbf{9}$ \\
\hline $\mathrm{RI}$ & 0 & 0 & 0.52 & 0.89 & 1.11 & 1.25 & 1.35 & 1.40 & 1.45 \\
\hline
\end{tabular}

Upon the acceptance of the $\mathrm{CR}$ percentages, the individual score is aggregated into group decision making. Two preferable aggregation methods are aggregation of individual judgments (AIJ) and aggregation of individual priorities (AIP). In this research, AIJ is an essential method in the model development procedure where group decision making is addressed as new "individual" result formation in the representation of the group decision as one [73]. The AIJ formula is as follows:

$$
X^{G}=\left[x_{i j}\right]^{G}=\prod_{n=1}^{m}\left(x_{i j}^{(n)}\right)^{\lambda^{k}}
$$

where $X^{G}$ is the collective or group matrix for all decision makers $(n=1 \ldots m=k$ th decision maker).

In accessing collective judgement, decision makers are considered to have different weight vectors. The weights depend on the level of the contribution to the decision-making process, such as experience, expertise, and performance hierarchy, where $\lambda^{k}$ is a value between 0 and 1 . However, who is responsible for and authorised in assigning weights for decision makers based on the hierarchy is questionable [73]. Therefore, in the event in which a decision maker considers weights to be equally important, then $\lambda^{k}=1 / m$. Then, row geometric mean method (RGMM) is selected for the prioritisation group decisionmaking method [74] using the following formula:

$$
w_{i}=\frac{\sqrt[1 / n]{\prod_{j=1}^{n} x_{i j}}}{\sum_{i=1}^{n}\left(\sqrt[1 / n]{\prod_{j=1}^{n} x_{i j}}\right)}
$$


In Equation (6), the collective weight is $w_{i}$ where $i=1,2 \ldots n$, and then the group consistency judgement is measured using the geometric consistency index (GCI) [75] as follows:

$$
G C I(X)=\frac{2}{(n-1)(n-2)} \sum_{i<j}\left(\left(\log x_{i j}\right)-\left(\log w_{i}\right)+\left(\log w_{j}\right)\right)^{2}
$$

Matrix $X=\left[x_{i j}\right]$ is considered acceptable if the generated value of GCI is consistent with the threshold value, as shown in Table 5.

Table 5. Geometric consistency index (GCI) threshold value [75].

\begin{tabular}{cc}
\hline GCI $(X)$ Value & Consistency Condition \\
\hline 0 & A is fully consistent \\
\hline 0.31 & $n=3$ \\
\hline 0.35 & $n=4$ \\
\hline 0.37 & $n>4$ \\
\hline
\end{tabular}

\section{AHP Results and Analysis}

In order to demonstrate how consensus judgement is applied in practice, strategic sub-elements are chosen to show how the AHP group judgment is used in the development of TDMF. Table 6 is the result of the pairwise comparison matrix performed by five decision makers (DM1 ... DM5).

Table 6. Strategic sub-element AHP-pairwise comparison.

\begin{tabular}{cccccc}
\hline Decision Maker/Sub-Elements & FVSG & DSCS & DFS & FMS \\
\hline \multirow{3}{*}{ DM1 } & FVSG & 1 & $1 / 7$ & $1 / 5$ & $1 / 5$ \\
& DSCS & 7 & 1 & 1 & 1 \\
& DFS & 5 & 1 & 1 & 1 \\
& FMS & 5 & 1 & 1 & 1 \\
\hline \multirow{5}{*}{ DM2 } & FVSG & 1 & 5 & $1 / 4$ & $1 / 3$ \\
& DSCS & $1 / 5$ & 1 & $1 / 5$ & $1 / 5$ \\
& DFS & 4 & 5 & 1 & 1 \\
& FMS & 3 & 5 & 1 & 1 \\
\hline \multirow{5}{*}{ DM3 } & FVSG & 1 & 1 & 1 & 1 \\
& DSCS & 1 & 1 & 3 & 3 \\
& DFS & 1 & $1 / 3$ & 1 & $1 / 4$ \\
& FMS & 1 & $1 / 3$ & 4 & 1 \\
\hline \multirow{5}{*}{ DM4 } & FVSG & 1 & $1 / 5$ & $1 / 5$ & $1 / 3$ \\
& DSCS & 5 & 1 & 1 & 5 \\
& DFS & 5 & 1 & 1 & 5 \\
& FMS & 3 & $1 / 5$ & $1 / 5$ & 1 \\
\hline & FVSG & 1 & $1 / 8$ & $1 / 9$ & $1 / 9$ \\
& DSCS & 8 & 1 & 1 & 1 \\
DM5 & DFS & 9 & 1 & 1 & 1 \\
& FMS & 9 & 1 & 1 & 1 \\
\hline
\end{tabular}

Individual attributes, such as decision-maker's weight priority vector $\left(w^{k} ; k=1 \ldots k\right.$-th $=$ decisionmaker), maximum eigenvalue $\left(\sigma_{\max }\right)$, consistency index $(\mathrm{CI})$, and consistency ratio $(\mathrm{CR})$ are summarized in Table 7. These attributes show variation in prioritized elements and the consistency in making judgments for each decision maker. The inconsistency value ranges from $0.08 \%$ to $17.51 \%$ for each strategic sub-element, which is in the reasonable range as explained in Section 2.4. The same procedure was applied to measure the individual attributes of other main element and their sub-elements. 
Table 7. Results on decision-makers' attributes on strategic sub-element.

\begin{tabular}{cc}
\hline Decision Makers & Individual Attribute \\
\hline & $w^{\mathrm{DM} 1}=\{0.0565,0.3330,0.3052,0.3052\}^{\mathrm{T}}$ \\
$\sigma_{\max }=4.0172$ \\
$\mathrm{CI}=0.0057$ \\
$\mathrm{CR}=0.64 \%$ \\
\hline DM2 & $w^{\mathrm{DM} 2}=\{0.1670,0.0619,0.4008,0.3703\}^{\mathrm{T}}$ \\
& $\sigma_{\max }=4.2795$ \\
& $\mathrm{CI}=0.0932$ \\
& $\mathrm{CR}=10.35 \%$ \\
\hline & $w^{\mathrm{DM} 3}=\{0.2316,0.3824,0.1334,0.2525\}^{\mathrm{T}}$ \\
& $\sigma_{\max }=4.4728$ \\
$\mathrm{CI}=0.1576$ \\
& $\mathrm{CR}=17.51 \%$ \\
\hline & $w^{\mathrm{DM} 4}=\{0.0669,0.4079,0.4079,0.1173\}^{\mathrm{T}}$ \\
& $\sigma_{\max }=4.2236$ \\
$\mathrm{CI}=0.0745$ \\
& $\mathrm{CR}=8.28 \%$ \\
& $w^{\mathrm{DM} 5}=\{0.0371,0.3148,0.3240,0.3420\}^{\mathrm{T}}$ \\
& $\sigma_{\max }=4.0022$ \\
& $\mathrm{CI}=0.0001$ \\
& $\mathrm{CR}=0.08 \%$ \\
\hline &
\end{tabular}

AIJ is used to aggregate the individual judgements to obtain the collective judgment upon the acceptance of an individual attribute. Then, RGMM is applied for the prioritization method. The collective judgement is presented in Table 8. One important observation is that the results obtained in Table 9 show a significant acceptance of the values of GCI, where GCI $<0.35$ for $n=4$ and GCI $<0.31$ for $n=3$.

Table 8. Collective judgement in decision making.

\begin{tabular}{|c|c|c|c|c|}
\hline Element/Sub-Elements & FVSG & DSCS & DFS & FMS \\
\hline \multirow{4}{*}{ SE } & 1.0000 & 0.4471 & 0.2565 & 0.3010 \\
\hline & 2.2369 & 1.0000 & 0.9029 & 1.2457 \\
\hline & 3.8981 & 1.1076 & 1.0000 & 1.0456 \\
\hline & 3.3227 & 0.8027 & 0.9564 & 1.0000 \\
\hline Element/Sub-elements & DCS & CG & COEM & CRI \\
\hline DCS & 1.0000 & 1.9473 & 0.9349 & 3.6801 \\
\hline CG & 0.5135 & 1.0000 & 0.5326 & 2.3714 \\
\hline COEM & 1.0696 & 1.8776 & 1.0000 & 3.1777 \\
\hline CRI & 0.2717 & 0.4217 & 0.3147 & 1.0000 \\
\hline Element/Sub-elements & DPL & DPC & FDDM & \\
\hline DPL & 1.0000 & 0.7740 & 1.5518 & \\
\hline $\mathrm{DPC}$ & 1.2920 & 1.0000 & 2.7241 & \\
\hline FDDM & 0.6444 & 0.3671 & 1.0000 & \\
\hline Element/Sub-elements & HRD & OV & SOE & \\
\hline HRD & 1.0000 & 1.5518 & 2.9302 & \\
\hline OV & 0.6444 & 1.0000 & 3.2453 & \\
\hline SOE & 0.3413 & 0.3081 & 1.0000 & \\
\hline Element/Sub-elements & SE & $\mathrm{TE}$ & $\mathrm{OE}$ & RE \\
\hline SE & 1.0000 & 1.3195 & 0.9417 & 2.6867 \\
\hline $\mathrm{TE}$ & 0.7579 & 1.0000 & 0.7860 & 2.0678 \\
\hline $\mathrm{OE}$ & 1.0619 & 1.2723 & 1.0000 & 1.9332 \\
\hline $\mathrm{RE}$ & 0.3722 & 0.4836 & 0.5173 & 1.0000 \\
\hline
\end{tabular}


Table 9. Consistency index of collective judgement.

\begin{tabular}{cccccc}
\hline $\begin{array}{c}\text { Consistency } \\
\text { Measures }\end{array}$ & $\begin{array}{c}\text { Strategic } \\
\text { Element }\end{array}$ & $\begin{array}{c}\text { Tactical } \\
\text { Element }\end{array}$ & $\begin{array}{c}\text { Operational } \\
\text { Element }\end{array}$ & $\begin{array}{c}\text { Reflexive } \\
\text { Element }\end{array}$ & $\begin{array}{c}\text { Main } \\
\text { Element }\end{array}$ \\
\hline GCI & 0.06 & 0.02 & 0.03 & 0.10 & 0.02 \\
\hline
\end{tabular}

Local and global ranks for the elements are calculated based on their prioritized weight value. The strategic element (SE) was found to be the most vital element (0.3196), followed by operational element (OE) (0.3006), tactical element (OE) (0.2491), and reflexive element (RE) (0.1306). Further analysis of the local rank of sub-elements and consensus judgement on the development of TDMF shows that development of financial strategy (DFS) (0.3304), core management process (DPC) (0.4750), development of organizational support (DOS) (0.3550), and human resources development (HRD) (0.4862) are the most essential sub-elements of a transitional framework into remanufacturing by AHP for each main element. Based on the lateral results of local rank analysis, the global rank of sub-elements is led by core management process (DPC) (0.1428), followed by development of financial strategy (DFS) (0.1056), formulation of marketing strategy (FMS) (0.0915), development of supply chain system (DSCS) (0.0912), and development of company structure (DOS) (0.0884). In contrast, the results found that collaboration with the government, organization valuation, formulation vision and goal, collaboration with research institute, and society engagement are of lesser priority. The final results are summarized in Table 10.

Table 10. Results on elements and sub-elements ranking.

\begin{tabular}{|c|c|c|c|c|c|c|}
\hline Element & $\begin{array}{c}\text { Priority } \\
\text { Weight }\left(w_{j}\right)\end{array}$ & Sub-Elements & $\begin{array}{c}\text { Local } \\
\text { Weight }\left(w_{i}\right)\end{array}$ & Global Weight & Local Rank & Global Rank \\
\hline \multirow{4}{*}{$\mathrm{SE}$} & \multirow{4}{*}{0.3196} & FVSG & 0.0977 & 0.0312 & 4 & 12 \\
\hline & & DSCS & 0.2855 & 0.0912 & 3 & 4 \\
\hline & & DFS & 0.3304 & 0.1056 & 1 & 2 \\
\hline & & FMS & 0.2864 & 0.0915 & 2 & 3 \\
\hline \multirow{4}{*}{$\mathrm{TE}$} & \multirow{4}{*}{0.2491} & DOS & 0.3550 & 0.0884 & 1 & 5 \\
\hline & & CG & 0.1980 & 0.0493 & 3 & 10 \\
\hline & & COEM & 0.3507 & 0.0873 & 2 & 6 \\
\hline & & CRI & 0.0962 & 0.0240 & 4 & 13 \\
\hline \multirow{3}{*}{$\mathrm{OE}$} & \multirow{3}{*}{0.3006} & DPL & 0.3319 & 0.0997 & 2 & 7 \\
\hline & & DPC & 0.4750 & 0.1428 & 1 & 1 \\
\hline & & FDDM & 0.1931 & 0.0581 & 3 & 8 \\
\hline \multirow{3}{*}{$\mathrm{RE}$} & \multirow{3}{*}{0.1306} & HRD & 0.4862 & 0.0635 & 1 & 9 \\
\hline & & OV & 0.3753 & 0.0490 & 2 & 11 \\
\hline & & SOE & 0.1385 & 0.0181 & 3 & 14 \\
\hline
\end{tabular}

\section{Discussion}

\subsection{Primary and Secondary Elements of TDMF}

Complexity and uncertainty in remanufacturing activity required the used of prescriptive decision-making approach in the development TDMF after the evaluation of prioritized element by AHP. The prescriptive approaches provide different alternative for each attribute in order to assist the decision maker's analyses their capabilities and proceed or shall not proceed in remanufacturing transition. Two categories are introduced in the proposed TDMF: (a) primary elements and (b) secondary elements in the application of TDMF.

(a) Primary Elements

Primary element consist of the first prioritized sub-element in the local rank and the top four prioritized elements in the global rank are grouped as the body structure of the core elements in TDMF. Each of the elements/sub-elements is a mandatory step to analyse the action during reviewing process by the decision makers without skipping any of them. These consist of: 
- Develop Financial Strength (DFS): Financial strength and its capabilities must be evaluated and a new financial scheme demanded if required for the suspension of the transition process [76] in its entirety.

- Formulate Marketing Strategies (FMS): Explore various marketing strategies depending on the category of the remanufacturing company [77] (i.e., whether the company is responsible as the original equipment manufacturer (OEM) remanufacturer or is an independent remanufacturer). The remanufacturer identity affects its identification for potential domestic or regional customers, as well as new export possibilities [78].

- Develop Supply Chain System (DSCS): Identify and implement multiple strategies in supply chain systems to optimize the core acquisition $[33,79]$. The relationships with multiple suppliers could benefit product-market strategies.

- Develop Core Management Process (DPC): Identify and evaluate the significant remanufacturing process flow in order to reduce unnecessarily repetitive procedures arising from the uncertainty of a core's quality $[48,50]$ in each department. An effective core management process would benefit in a cost-effective production process [80].

- Develop Company Structure (DOS): Re-evaluate the necessity of a remanufacturing division internally or as a whole organization in order to support and enhance the remanufacturing process during and after the transition period.

- Human Resources Development (HRD): Continuous professional training development must be adequately provided to employees, thereby allowing competent employees to be responsible for the introduction of new engineering business practices [81].

(b) Secondary Elements

The secondary elements consist of the remaining prioritized element/sub-element based on the local rank as well as global rank. In contrast with the primary element/sub-elements, decision makers are more flexible and allowed to reconsider option provided. These consist of:

- Formulate Vision and Goal (FVSG): Determine the company's long-term direction, goals, and achievements for the transitional operation. Identify the short-term actions required to realize the vision and periodically reassess them.

- Develop Production Layout (DPL): Redesign the layout system and facilities arrangement based on the size of the site location to optimize the current workplace with an effective flow process.

- Formulate Data and Document Management (FDDM): Design and provide a practical documentation management system in order to record current and new practice implementation information for the purpose of internal audits or audits by the authorities.

- Collaborate with OEM (COEM): Develop a cooperation strategy with the OEM for the benefits of sharing intellectual property knowledge and strengthening the marketing channel for remanufactured products.

- Collaborate with Government (CG): Develop collaboration with government agencies, such as MARii, Malaysian Investment Development Authority (MIDA), and Road Transport Department Malaysia to benefit from the development of policies, tax exemptions, and incentives for the Malaysian remanufacturing industry.

- Collaborate with Research Institutes (CRI): Consider investing in a research institute partnership when implementing reverse engineering processes to increase the engineering data precision if the OEM is not willing to collaborate [82].

- Organization Valuation (OV): Re-examine and periodically reassess company performance in remanufacturing to verify it is in line with expectations and achieving the sustainability objective while generating profit.

- Society Engagement (SOE): The company may consider providing an avenue for customers to provide feedback [83] if the product's remanufacturing improvements dependent on it. 


\subsection{The Relation between Transition Decision-Making with Open Innovation}

As remanufacturing has become preferable innovative sustainability in manufacturing, the emphasis is on the necessity for multi-criteria analysis in transitional decision-making management. The transitional decision-making resulted with combination process of required inflow and outflow of knowledge which also the basic principle for the implementation of an open innovation [84] to enhance the internal change of an organization with the broad effect of the potential market, as apparent benefits of innovation [85]. Chiaroni et al. [85] introduced a theoretical framework of open innovation implementation, which includes four significant aspects (i.e., networks, organisational structures, evaluation processes, and knowledge management systems). This section discusses how the results of transitional decision-making create a substantial channel on managerial and organisational strategies towards open innovation adoption according to these four significant aspects.

Network innovation relates to varieties of relationship, such as the partnership between supply chain and supplier, particular collaboration, and user-relationship. These networks serve a different purpose and should be managed based on organization capability. Flexibility, in the supply chain relationship, is the best way for an organization to achieve outbound open innovation adoption within the transition process. Flexibility provides multiple supply chain activity alternatives, such as service-contract, ownership-based, direct order, deposit based, buy back, or voluntary based [79]. These supply chain management strategies are beneficial in expanding potential external channels for remarketing remanufactured products. Focus on specific options may cause limited resources and affect the company's development. Meanwhile, open innovation inbound strategies, such as collaboration between an organization and universities, research institutes, or even the OEM, will establish a better platform to enhance business competitiveness, while accessing technical and scientific knowledge.

Data restriction and document control, which may exist in an external coalition strategy, limits open innovation implementation. Prior to this paper, intellectual properties of original product rights were restricted by the OEM due to the perception of cannibalization effects on new products and the uncertainty of remanufactured products by third party enterprises. However, an open innovation system leads to the approach of innovation in a knowledge management system. An organization can exploit research institute expertise and universities for the primary purpose of generating, sharing and knowledge transfer. Furthermore, this paper highlights the importance of the evaluation process; such as the analysis of financial capability during the early transition process, core management process, and organization valuation after transition. The main reason for the evaluation process during the implementation of open innovation is that gathered information benefits the continuous development of social change impacts according to the external environment, while ensuring the prospective profits that result from innovation. For the last aspect of open innovation implementation, the establishment of a healthy organization structure based on internal network and support is required. Yun et al. [86] found that, based on case studies conducted in Korean small and medium sized enterprises (SMEs), the approach and government of managerial levels could promote the implementation of open innovation. Therefore, companies may consider full transition business practice or integration of existing current business objectives with new business ideas that could be successfully achieved by joint cross-functional teams. The adoption of this aspect will allow the flexibility implementation and re-orientation of the internal organization depending on market pathway.

\section{Conclusions}

Sustainable engineering practice demanding collaboration from different organization and stakeholders due the differences in perspective. Two case studies were conducted to gain knowledge and refine the identified 14 sub-elements, which were then categorized into four major transition elements based on real life engineering practice through interview, site observation, and recording related information's. Application of AHP allowed evaluation of prioritized element and sub-elements, which was done with selected experts in pairwise comparison process. Therefore, the study successfully identified six prioritized sub-elements for primary elements and secondary elements for the remaining 
weighted sub-elements with necessary actions provided. It was designed for a transition guideline tool based on the analysis procedure as discussed in Section 4 for development of TDMF. TDMF could be of benefit to enterprises in analysing the impact-selection actions and gaining the decision-making knowledge to transition towards remanufacturing automotive parts in Malaysia.

Still, the research has some limitations and required further actions. The limitation of the research is the involvement of other authority, agency, and industrial players which are involved in repair, remanufacturing, reconditioning, and recycle. It may also be limited due to confidentiality or time constraints. Generating individual consistency ratio values of less than 10 percent might be impractical since it would need iteration procedures. Some respondents might get irritated and give up on participation. For future study, the comparative study on the suitable application of TDMF for as start-up remanufacturing company, especially in automotive sector, or the transition of remanufacturing in other engineering areas such as electric and electronic could be done. Thorough exploration in this research will benefit knowledge gain for directing remanufacturing status and progress in Malaysia.

Author Contributions: M.F.R.M. has designed the research, conducted formal analysis and writing the original draft of this manuscript; E.N.R. and N.M.N. has contributed in providing the resource, research supervision, review and editing the manuscript. All authors read and approved the final manuscript.

Funding: This research received no external funding.

Conflicts of Interest: The authors declare no conflict of interest.

\section{Appendix A}

Table A1. Respondent guideline in pairwise comparison survey.

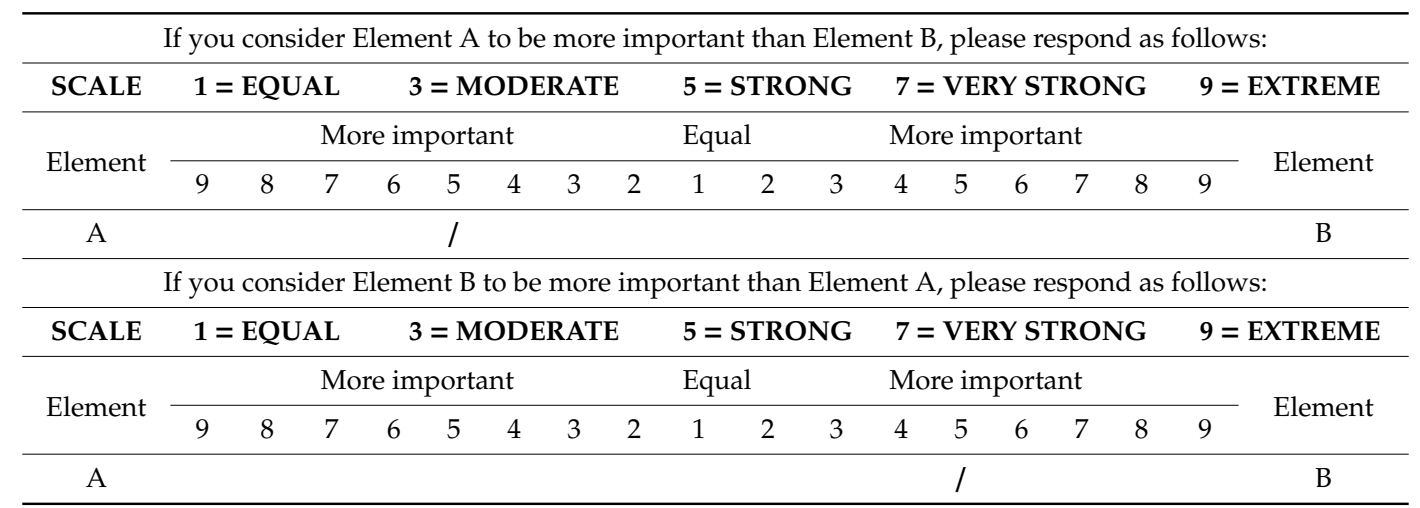

\section{References}

1. Ferrer, G.; Ayres, R.U. The impact of remanufacturing in the economy. Ecol. Econ. 2000, 32, 413-429. [CrossRef]

2. Liu, Z.; Jiang, Q.; LI, T.; Dong, S.; Yan, S.; Zhang, H.; Xu, B. Environmental benefits of remanufacturing: A case study of cylinder heads remanufactured through laser cladding. J. Clean. Prod. 2016, 133, 1027-1033. [CrossRef]

3. Yang, S.S.; Ngiam, H.Y.; Ong, S.K.; Nee, A.Y.C. The impact of automotive product remanufacturing on environmental performance. Procedia CIRP 2015, 29, 774-779. [CrossRef]

4. Raz, G.; Ovchinnikov, A.; Blass, V. Economic, Environmental, and Social Impact of Remanufacturing in a Competitive Setting. IEEE Trans. Eng. Manag. 2017, 64, 76-490. [CrossRef]

5. Govindan, K.; Shankar, K.M.; Kannan, D. Application of fuzzy analytic network process for barrier evaluation in automotive parts remanufacturing towards cleaner production-A study in an Indian scenario. J. Clean. Prod. 2015, 114, 199-213. [CrossRef]

6. Ijomah, W.L.; McMahon, C.A.; Hammond, G.P.; Newman, S.T. Development of design for remanufacturing guidelines to support sustainable manufacturing. Robot. Comput. Integr. Manuf. 2007, 23, 712-719. [CrossRef]

7. Zhang, J.H.; Yang, B.; Chen, M. Challenges of the development for automotive parts remanufacturing in China. J. Clean. Prod. 2016, 140, 1087-1094. [CrossRef] 
8. Jiang, Z.; Zhang, H.; Sutherland, J.W. Development of multi-criteria decision making model for remanufacturing technology portfolio selection. J. Clean. Prod. 2011, 19, 1939-1945. [CrossRef]

9. Matsumoto, M.; Umeda, Y. An analysis of remanufacturing practices in Japan. J. Remanufacturing 2011, 1, 1-11. [CrossRef]

10. Saavedra, Y.M.B.; Barquet, A.P.B.; Rozenfeld, H.; Forcellini, F.A.; Ometto, A.R. Remanufacturing in Brazil: Case studies on the automotive sector. J. Clean. Prod. 2013, 53, 267-276. [CrossRef]

11. Sharma, V.; Garg, S.K.; Sharma, P.B. Identification of major drivers and roadblocks for remanufacturing in India. J. Clean. Prod. 2014, 112, 1882-1892. [CrossRef]

12. Chaowanapong, J.; Jongwanich, J.; Ijomah, W. The determinants of remanufacturing practices in developing countries: Evidence from Thai industries. J. Clean. Prod. 2018, 170, 369-378. [CrossRef]

13. Yusop, N.M.; Wahab, D.A.; Saibani, N. Analysis of remanufacturing practices in the malaysian automotive industry. J. Teknol. 2012, 59, 77-80.

14. APEC. Centre of Remanufacturing and Reuse, Remanufacturing in Malaysia An Assessment of the Current and Future; APEC: Maynila, Philippines, 2015; p. 57.

15. Misran, M.F.R.; Roslin, E.N. Challenges and Barriers to the Implementation of Automotive Remanufacturing in Malaysia: A Review. J. Adv. Res. Dyn. Control. Syst. 2018, 10, 17-22.

16. van Hemel, C.; Cramer, J. Barriers and stimuli for ecodesign in SMEs. J. Clean. Prod. 2002, 10, 439-453. [CrossRef]

17. Halbe, J.; Pahl-wostl, C. A Methodological Framework to Initiate and Design Transition Governance Processes. Sustainability 2019, 11, 844. [CrossRef]

18. VoSS, J.P.; Kemp, R. Sustainability and reflexive governance: Introduction. In Reflexive Governance for Sustainable Development; Edward Elgar Publishing: Cheltenham, UK, 2006; pp. 3-28.

19. Folke, C.; Colding, J.; Berkes, F. Synthesis: Building Resilience and Adaptive Capacity in Social-Ecological Systems; Cambridge University Press: Cambridge, UK, 2002.

20. Pahl-Wostl, C. The implications of complexity for integrated resources management. Environ. Model. Softw. 2007, 22, 561-569. [CrossRef]

21. Foxon, T.; Stringer, L.; Reed, M. Comparing adaptive management and transition management. Ökologisches Wirtsch. Fachz. 2008, 20-22. [CrossRef]

22. Haxeltine, A.; Whitmarsh, L.; Bergman, N.; Rotmans, J.; Schilperoord, M.; Kohler, J. A conceptual framework for transition modelling. Int. J. Innov. Sustain. Dev. 2008, 3, 93-114. [CrossRef]

23. de Haan, J. Pillars of change: A theoretical framework for transition models. In Proceedings of the 7th International Conference of the European Society for Ecological Economics (ESEE), Leipzig, Germany, 5-8 June 2007.

24. Stephens, J.C.; Graham, A.C. Toward an empirical research agenda for sustainability in higher education: Exploring the transition management framework. J. Clean. Prod. 2010, 18, 611-618. [CrossRef]

25. Loorbach, D.; van Bakel, J.C.; Whiteman, G.; Rotmans, J. Business Strategies for Transitions Towards Sustainable Systems. Bus. Strateg. Environ. 2010, 19, 133-146. [CrossRef]

26. Boons, F.; Montalvo, C.; Quist, J.; Wagner, M. Sustainable innovation, business models and economic performance: An overview. J. Clean. Prod. 2013, 45,1-8. [CrossRef]

27. Yin, R.K. Case Study Research: Design and Methods; Sage Publication: Beverly Hills, CA, USA, $1984 ;$ p. 5.

28. Misran, M.F.R.; Roslin, E.N.; Nur, N.M.; Othman, J. Transition Decision-Making Framework for Remanufacturing: A Case Study in Malaysia Automotive Sector. Test Eng. Manag. 2020, 83, 1079-1086.

29. Martens, M.L.; Carvalho, M.M. Key factors of sustainability in project management context: A survey exploring the project managers' perspective. Int. J. Proj. Manag. 2017, 35, 1084-1102. [CrossRef]

30. Sühlsen, K.; Hisschemöller, M. Lobbying the 'Energiewende'. Assessing the effectiveness of strategies to promote the renewable energy business in Germany. Energy Policy 2014, 69, 316-325. [CrossRef]

31. Ying, J.; Li-jun, Z. Study on Green Supply Chain Management Based on Circular Economy. Phys. Procedia 2012, 25, 1682-1688. [CrossRef]

32. Xia, W.H.; Jia, D.Y.; He, Y.Y. The remanufacturing reverse logistics management based on closed-loop supply chain management processes. Procedia Environ. Sci. 2011, 11, 351-354.

33. AlSagheer, A.; Ahli, M. Impact Of Supply Chain Integration On Business Performance And Its Challenges. Int. Bus. Econ. Res. J. 2011, 10, 79-92. [CrossRef]

34. Subramoniam, R.; Huisingh, D.; Chinnam, R.B. Remanufacturing for the automotive aftermarket-strategic factors: Literature review and future research needs. J. Clean. Prod. 2009, 17, 1163-1174. [CrossRef] 
35. Wei, S.; Tang, O.; Sundin, E. Core (product) Acquisition Management for remanufacturing: A review. J. Remanufacturing 2015, 5, 1-27. [CrossRef]

36. Nasiri, M.; Rantala, T.; Saunila, M.; Ukko, J.; Rantanen, H. Transition towards sustainable solutions: Product, service, technology, and business model. Sustainability 2018, 10, 358. [CrossRef]

37. Ghazilla, R.A.R.; Sakundarini, N.; Abdul-Rashid, S.H.; Ayub, N.S.; Olugu, E.U.; Musa, S.N. Drivers and barriers analysis for green manufacturing practices in Malaysian smes: A preliminary findings. Procedia CIRP 2015, 26, 658-663. [CrossRef]

38. McAdam, R.; McConvery, T.; Armstrong, G. Barriers to innovation within small firms in a peripheral location. Int. J. Entrep. Behav. Res. 2004, 10, 206-221. [CrossRef]

39. Guidat, T.; Seidel, J.; Kohl, H.; Seliger, G. A Comparison of Best Practices of Public and Private Support Incentives for the Remanufacturing Industry. Procedia CIRP 2017, 61, 177-182. [CrossRef]

40. Li, B.; Wang, Z.; Wang, Y.; Tang, J.; Zhu, X.; Liu, Z. The effect of introducing upgraded remanufacturing strategy on OEM's decision. Sustainability 2018, 10, 828. [CrossRef]

41. Karvonen, I.; Jansson, K.; Tonteri, H.; Vatanen, S.; Uoti, M. Enhancing remanufacturing-Studying networks and sustainability to support Finnish industry. J. Remanufacturing 2015, 5, 5. [CrossRef]

42. Mitra, S.; Webster, S. Competition in remanufacturing and the effects of government subsidies. Int. J. Prod. Econ. 2008, 111, 287-298. [CrossRef]

43. Buhalis, D.; Main, H. Information technology in peripheral small and medium hospitality enterprises. Int. J. Contemp. Hosp. Manag. 1998, 5, 198-202. [CrossRef]

44. Kang, H.; Jun, Y.; Kim, Y.; Jo, H. Comparative Analysis on Cross-national System to Enhance the Reliability of Remanufactured Products. Procedia CIRP 2016, 40, 280-284. [CrossRef]

45. Naqvi, S.A.A.; Fahad, M.; Atir, M.; Zubair, M.; Shehzad, M.M. Productivity improvement of a manufacturing facility using systematic layout planning. Cogent Eng. 2016. [CrossRef]

46. Drira, A.; Pierreval, H.; Hajri-Gabouj, S. Facility layout problems: A survey. Annu. Rev. Control. 2007, 31, 255-267. [CrossRef]

47. Lim, H.H.; Noble, J.S. The impact of facility layout on overall remanufacturing system performance. Int. J. Ind. Syst. Eng. 2006, 1, 357-370. [CrossRef]

48. Teunter, R.H.; Flapper, S.D.P. Optimal core acquisition and remanufacturing policies under uncertain core quality fractions. Eur. J. Oper. Res. 2011, 210, 241-248. [CrossRef]

49. Kin, S.T.M.; Ong, S.K.; Nee, A.Y.C. Remanufacturing process planning. Procedia CIRP 2014, 15, $189-194$. [CrossRef]

50. Kurilova-Palisaitiene, J.; Sundin, E.; Poksinska, B. Remanufacturing challenges and possible lean improvements. J. Clean. Prod. 2018, 172, 3225-3236. [CrossRef]

51. Tattersall, A. Business process transition: Managing a successful business process transition in a multinational organization. Inf. Serv. Gr. 2013, pp. 1-11. Available online: https://isg-one.com/docs/default-source/defaultdocument-library/58-managing-successful_interactive.pdf?sfvrsn=905ef831_0 (accessed on 10 August 2020).

52. Yu, L.C.; Hui, H.Y. An empirical study on logistics service providers' intention to adopt green innovations. J. Technol. Manag. Innov. 2008, 3, 17-26.

53. Arredondo-Soto, K.C.; Realyvasquez-Vargas, A.; Maldonado-Macías, A.A.; García-Alcaraz, J. Impact of human resources on remanufacturing process, internal complexity, perceived quality of core, numerosity, and key process indicators. Robot. Comput. Integr. Manuf. 2019, 59, 168-176. [CrossRef]

54. Ahamed, S.T.; Niyas, P.T.M.; Rifky, A.L.M. Identify the Significance of Performance Appraisals on Employee Work Improvement in Software Development Organizations. Int. J. Sci. Res. Publ. 2018, 8, 399-404. [CrossRef]

55. Medvecká, I.; Biňasová, V.; Kubinec, L. Planning and Performance Evaluation of the Manufacturing Organizations. Procedia Eng. 2017, 192, 46-51. [CrossRef]

56. Ali, S.I.; Yousof, J.; Khan, M.R.; Masood, S.A. Evaluation of performance in manufacturing organization through productivity and quality. Afr. J. Bus. Manag. 2011, 5, 2211-2219.

57. Khor, K.S.; Hazen, B.T. Remanufactured products purchase intentions and behaviour: Evidence from Malaysia. Int. J. Prod. Res. 2017, 55, 2149-2162. [CrossRef]

58. Steingrímsson, J.G.; Bilge, P.; Heyer, S.; Seliger, G. Business Strategies for Competition and Collaboration for Remanufacturing of Production Equipmen. In Advance in Sustainable Manufacturing; Springer: Berlin, Germany, 2011; pp. 91-97. 
59. Sabaei, D.; Erkoyuncu, J.; Roy, R. A review of multi-criteria decision making methods for enhanced maintenance delivery. Procedia CIRP 2015, 37, 30-35. [CrossRef]

60. Velasquez, M.; Hester, P.T. An Analysis of Multi-Criteria Decision Making Methods. Int. J. Oper. Res. 2013, 10, 56-66.

61. Taherdoost, H. Decision Making Using the Analytic Hierarchy Process (AHP); A Step by Step Approach. Int. J. Econ. Manag. Syst. 2018, 2, 244-246.

62. Wheelwright, S.C. Reflecting corporate strategy in manufacturing decisions. Bus. Horizons 1978, $21,57-66$. [CrossRef]

63. Russo, R.D.F.S.M.; Camanho, R. Criteria in AHP: A systematic review of literature. Procedia Comput. Sci. 2015, 55, 1123-1132. [CrossRef]

64. Saaty, T.L. Decision making with the analytic hierarchy process. Int. J. Serv. Sci. 2008, 1, 83. [CrossRef]

65. Kil, S.H.; Lee, D.K.; Kim, J.H.; Li, M.H.; Newman, G. Utilizing the analytic hierarchy process to establish weighted values for evaluating the stability of slope revegetation based on hydroseeding applications in South Korea. Sustainability 2016, 8, 58. [CrossRef]

66. Ulkhaq, M.M.; Wijayanti, W.R.; Zain, M.S.; Baskara, E.; Leonita, W. Combining the AHP and TOPSIS to evaluate car selection. In Proceedings of the 2nd International Conference on High Performance Compilation, Computing and Communications, Hongkong, China, 15-17 March 2018; pp. 112-117.

67. Melillo, P.; Pecchia, L. What Is the Appropriate Sample Size To Run Analytic Hierarchy Process in a Survey-Based Research? In Proceedings of the The International Symposium on the Analytic Hierarchy Process, London, UK, 4-8 August 2016.

68. Huang, R.Y.; Yeh, C.H. Development of an assessment framework for green highway construction. J. Chin. Inst. Eng. 2008, 31, 573-585. [CrossRef]

69. Paleie, I.; Lalic, B. Analytical hierarchy process as a tool for selecting and evaluating projects. Int. J. Simul. Model. 2009, 8, 16-26.

70. Ijzerman, M.J. Group Decision Making with the Analytic Hierarchy Process in Benefit-Risk Assessment: A Tutorial. Patient 2014, 7, 129-140.

71. Ho, D.; Newell, G.; Walker, A.; Newell, G. The importance of property-specific attributes in assessing CBD office building quality. J. Prop. Invest. Financ. 2006, 23, 424-444. [CrossRef]

72. Chen, P.S.; Chu, P.; Lin, M. On Vargas's proof of consistency test for $3 \times 3$ comparison matrices in AHP. J. Oper. Res. Soc. Jpn. 2002, 45, 233-242. [CrossRef]

73. Forman, E.; Peniwati, K. Aggregating individual judgments and priorities with the Analytic Hierarchy Process. Eur. J. Oper. Res. 1998, 108, 165-169. [CrossRef]

74. Dong, Y.; Zhang, G.; Hong, W.C.; Xu, Y. Consensus models for AHP group decision making under row geometric mean prioritization method. Decis. Support Syst. 2010, 49, 281-289. [CrossRef]

75. Moreno-Jiménez, J.A.; María, J. The geometric consistency index: Approximated thresholds. Eur. J. Oper. Res. 2003, 147, 137-145.

76. Bolton, R.; Hannon, M. Governing sustainability transitions through business model innovation: Towards a systems understanding. Res. Policy 2016, 45, 1731-1742. [CrossRef]

77. Kutlu, M.B. Marketing for core acquisition and remarketing of remanufactured products. In Proceedings of the The LCBR European Marketing Conference, Lisbon, Portugal, 28-28 June 2016.

78. Govindan, K.; Beatriz, J.-P.; Sergio, R.; María, A.; Vicente, M. Marketing issues for remanufactured products Kannan. J. Clean. Prod. 2019. [CrossRef]

79. Wei, S.; Cheng, D.; Sundin, E.; Tang, O. Motives and barriers of the remanufacturing industry in China. J. Clean. Prod. 2015, 94, 340-351. [CrossRef]

80. Casper, R.; Sundin, E. Addressing Today's challenges in automotive remanufacturing. J. Remanufacturing 2018, 8, 93-102. [CrossRef]

81. Abadijoo, M.; Moghadam, M.N.; Beheshtifar, M. Role of Human Resource Development in the Organization Success. J. Soc. Issues Humanit. 2015, 3, 44-47.

82. Gunasekara, H.; Gamage, J.; Punchihewa, H. Remanufacture for Sustainability: A review of the barriers and the solutions to promote remanufacturing. In Proceedings of the 2018 International Conference on Production and Operations Management Society (POMS), Peradeniya, Sri Lanka, 14-16 December 2018.

83. Liu, W.; Moultrie, J.; Ye, S. The Customer-Dominated Innovation Process: Involving Customers as Designers and Decision-Makers in Developing New Product. Des. J. 2019, 22, 299-324. [CrossRef] 
84. Henkel, J.; Schöberl, S.; Alexy, O. The emergence of openness: How and why firms adopt selective revealing in open innovation. Res. Policy 2014, 43, 879-890. [CrossRef]

85. Chiaroni, D.; Chiesa, V.; Frattini, F. The Open Innovation Journey: How firms dynamically implement the emerging innovation management paradigm. Technovation 2011, 31, 34-43. [CrossRef]

86. Yun, J.J.; Park, K.; Kim, J.; Yang, J. Open Innovation Effort, Entrepreneurship Orientation and their Synergies onto Innovation Performance in SMEs of Korea. Sci. Technol. Soc. 2016, 21, 366-390. [CrossRef]

(C) 2020 by the authors. Licensee MDPI, Basel, Switzerland. This article is an open access article distributed under the terms and conditions of the Creative Commons Attribution (CC BY) license (http://creativecommons.org/licenses/by/4.0/). 